\title{
PENGEMBANGAN MODUL DENGAN PENDEKATAN OPEN ENDED UNTUK MEMFASILITASI PENCAPAIAN LITERASI MATEMATIS
}

\author{
Agung Putra Wijaya \\ Universitas Lampung \\ E-mail: agung.wijaya@fkip.unila.ac.id
}

\begin{abstract}
This research and development aimed to develop module with an open ended approach to facilitate the achievement of mathematical literacy. This study was conducted only until the field trial and the revision of product. The module was validated by experts with attention to aspects: matter, appearance, and practicality. Having been declared valid by experts, the test readability by the students was done. Based on the steps, it was obtained (1) the use of the module with an open ended approach in Linier Programmingwas expected by the students, (2) the module characteristics were in accordance with the curriculum and designed in accordance with the open-ended approach, (3) the experts responses to the module were appropriate in terms of aspects of matter, appearance, and practicality and (4) the students responses were good viewed by readability.
\end{abstract}

Keywords: methematical literacy, open ended, linear programming

\section{PENDAHULUAN}

Matematika merupakan mata pelajaran yang senantiasa diajarkan pada setiap jenjang pendidikan, mulai dari sekolah dasar sampai ke perguruan tinggi. Karakteristik matematika berbeda dengan karakteristik ilmu lainnya. Pengetahuan matematika adalah pengetahuan yang dibentuk melalui proses berpikir tentang pengalaman akan sesuatu objek atau kejadian tertentu (Johar, 2012). Menurut Gallgher \& Reid (Suparno, 2001), pengetahuan ini diperoleh dari abstraksi berdasarkan koordinasi, relasi, atau penggunaan objek (abstraksi reflektif). Pengetahuan matematika dapat berkembang hanya bila anak bertindak terhadap objek itu.Belajar matematika di tingkat perguruan tinggi umumnya melibatkan kemampuan kognitif tingkat tinggi, seperti kemampuan analisis, sintesis, dan evaluasi, bukan sekedar mengingat pengetahuan faktual ataupun aplikasi sederhana dari berbagai formula atau prinsip. Menurut Moise (Ayers et al., 1988), hal ini menyebabkan banyak mahasiswa mengalami kesulitan dalam mempelajari topik-topik standar yang terdapat dalam kurikulum perguruan tinggi.

Mata kuliah program linier merupakan salah satu mata kuliah wajib dalam kurikulum jurusan/program studi matematika dan pendidikan matematika di semua Perguruan Tinggi di Indonesia.Lingkup bahasan mata kuliah ini meliputi: metode grafis, metode simpleks, metode Big $\mathrm{M}$, masalah degenerasi, primal-dual persoalan linear, masalah transportasi, dan masalah penugasan. Melalui perkuliahan ini, mahasiswa diharapkan mampu mengembangkan kemampuan 
dalam memformulasikan masalahmasalah pengambilan keputusan.

Berdasarkan pengalaman sebagai dosen pengampu mata kuliah program linier, literasi matematis mahasiswa masih rendah. Sebagian besar mahasiswa mengalami kesulitan dalam (1) memahami permasalahan matematis yang ada di sekitarnya yang terkait dengan matematika; (2) membaca dan menyajikan representasi matematis dari masalah yang dihadapi; (3) menyelesaikan permasalahan matematis yang dihadapi; dan (4) mengkomunikasikan gagasan secara matematis terkait dengan masalah matematika yang dijumpai dalam kehidupan nyata. Kesulitan lain yang dialami mahasiswa adalah tidak mampu dalam menyatakan model matematis yang disajikan ke dalam suatu permasalahan yang sesuai. Selama ini, mahasiswa terbiasa dalam menyatakan permasalahan ke dalam model matematis, namun tidak terbiasa untuk menyatakan model matematis ke dalam permasalahan.

Rendahnya literasi matematis ini perlu mendapat perhatian tersendiri (OECD, 2013). Literasi matematis membantu seseorang untuk mengenal peran matematika dalam dunia dan membuat pertimbangan maupun keputusan yang dibutuhkan sebagai warga negara. Seiring dengan perkembangan zaman, semua orang perlu memiliki literasi matematis untuk membantu menghadapi berbagai permasalahan. Hal ini disebabkan literasi matematika sangat penting bagi semua orang terkait dengan pekerjaan dan tugasnya dalam kehidupan seharihari.

Pembelajaran matematika yang terjadi saat ini belum mengarah pada pencapaian literasi matematis. Pembelajaran yang terjadi sebatas pada transfer ilmu dari pendidik ke peserta didik. Pembelajaran yang berlangsung seolah tidak memedulikan apakah peserta didik mampu merepresentasikan masalah yang dihadapi dan mengkomunikasikan gagasannya secara sistematis. Pemberian masalah tidak bersifat open, artinya masalah yang disajikan hanya memiliki satu jawaban benar. Apabila peserta didik tidak menjawab persis demikian, maka jawaban peserta didik salah.

Mencermati fenomena tersebut, menurut Suherman (2003) dan Wena (2009) diperlukan adanya inovasi pembelajaran dengan melibatkan media pembelajaran yang memberikan kesempatan kepada peserta didik untuk lebih mengekspresikan ide matematisnya dalam menyelesaikan open problems guna pencapaian literasi matematisnya. Penggunaan media pembelajaran dapat diawali dengan satuan media terkecilmenurut Depdiknas (2008) dan Asyhar (2011), yaitu modul pembelajaran. Hal ini dimaksudkan agar peserta didik perlahan-lahan mampu mengikuti perubahan paradigma pembelajaran guna mencapai tujuan pembelajaran.

Melalui

penerapan pendekatan open-ended, pembelajaran yang berlangsung akan mampu memberikan kesempatan pada peserta didik untuk belajar melalui aktivitasaktivitas real life dengan menyajikan fenomena alam seterbuka mungkin pada peserta didik (Shimada\&Becker, 1997). Bentuk penyajian fenomena dengan terbuka ini dapat dilakukan melalui pembelajaran yang berorientasi pada masalah atau soal atau tugas terbuka. Secara konseptual, masalah terbuka dalam pembelajaran matematika adalah masalah atau soal-soal matematika yang dirumuskan sedimikian rupa, sehingga memiliki beberapa atau bahkan banyak solusi yang benar, dan terdapat banyak 
cara untuk mencapai solusi itu (Sugiman, 2008).

Melalui penggunaan modul yang mampu memberikan kesempatan pada peserta didik untuk belajar melalui aktivitas-aktivitas real life dengan menyajikan fenomena alam seterbuka mungkin, diharapkan mampu memfasilitasi pencapaian literasi matematis peserta didik. Dengan demikian, pengembangan modul dengan pendekatan open ended dalam perkuliahan Program Linier mutlak diperlukan untuk memfasilitasi pencapaian literasi matematis mahasiswa.

\section{METODE PENELITIAN}

Metode yang digunakan adalah penelitian dan pengembangan. Penelitian ini menghasilkan produk tertentu yang didasarkan dari analisis kebutuhan dan pengujian keefektifan produk tersebut supaya dapat berfungsi di masyarakat (Sugiyono, 2008). Sukmadinata (2011) menyatakan bahwa research and development adalah suatu proses untuk mengembangkan suatu produk baru atau menyempurnakan produk yang telah ada, yang dapat dipertanggungjawabkan. Menurut Borg dan Gall, 1989 (dalam Sukmadinata, 2011) ada sepuluh langkah dalam pelaksanaan strategi penelitian dan pengembangan, yaitu (1) Penelitian dan pengumpulan data; (2) Perencanaan; (3) Pengembangan draf produk; (4) Uji coba lapangan awal; (5) Merevisi hasil uji coba; (6) Uji coba lapangan; (7) Penyempurnaan produk hasil uji lapangan; (8) Uji pelaksanaan lapangan; (9) Penyempurnaan produk akhir; dan (10) Diseminasi dan implementasi. Digambarkan oleh Borg dan Gall dalam Sugiyono (2008) seperti pada Gambar 1.

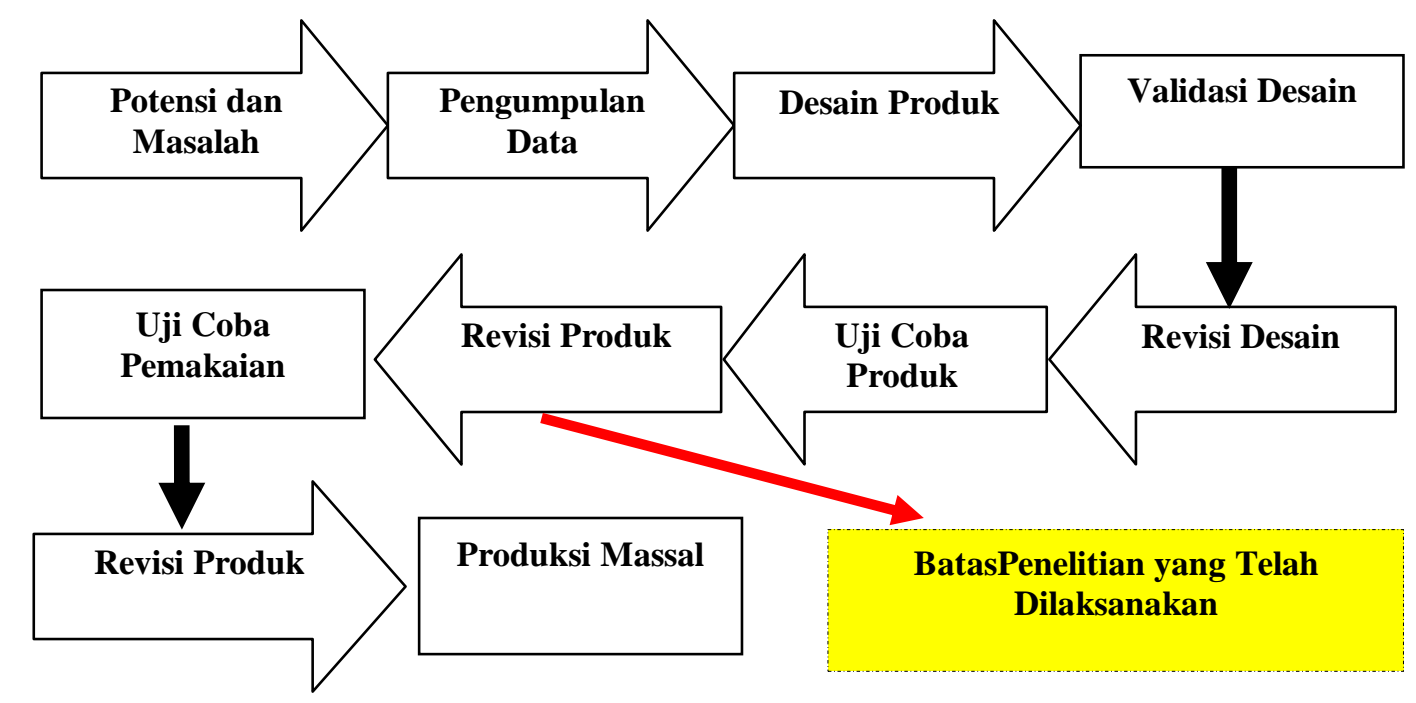

Gambar 1. Langkah-Langkah Metode Research and Development (R\&D)

Dalam penelitian ini, langkah-langkah penelitian yang dilakukan hanya sampai tahap uji coba lapangan awal (preliminary field testing) dan revisi hasil uji coba produk (main product revision) secara terbatas.
Subjek penelitian ini adalah modul dengan pendekatan open ended.Penelitian ini dilaksanakan di Program Studi Pendidikan Matematika FKIP Unila. Tahap studi lapangan dilakukan dengan menganalisis hasil observasi selama mengampu mata 
kuliah Program Linier selama 2 tahun terakhir. Tahap pengembangan modul ini melibatkan mahasiswa Program Studi Pendidikan Matematika FKIP Unila yang menempuh mata kuliah Program Linier. Sumber data penelitian ini adalah dosen pengampu dan mahasiswa yang menempuh mata kuliah Program Linier. Pada tahap studi pendahuluan, sumber data berasal dari 2 orang dosen yang mengampu mata kuliah Program Linier dan 20 mahasiswa Program Studi Pendidikan Matematika FKIP Unila yang menempuh mata kuliah Program Linier. Pada tahap uji coba terbatas menggunakan angket dalam mengumpulkan data. Sumber data pada tahap uji coba terbatas ini terdiri dari dua orang dosen (ahli) dan 10 mahasiswa Program Studi Pendidikan Matematika FKIP Unila yang menempuh mata kuliah Program Linier.

Berdasarkan pada tujuan penelitian, dirancang dan disusun instrumen penelitian. Instrumen yang digunakan pada studi lapangan berupa catatan lapangan atau lembar observasi untuk mengetahui karakteristik pembelajaran dan bagaimana mahasiswa belajar. Selain itu, juga digunakan instrumenangket. Angket ini diisi olehmahasiswa dengan tujuan untuk mengetahui modul yang sesuai dengan kebutuhan mahasiswa dan sebagai masukan dalam pengembangan modul.Instrumen ini berbentuk angket validasi aspek materi untuk memvalidasi apakah isi modultelah sesuaidengan kompetensi dasar yang ditetapkan dalam kurikulum. Selain itu, juga divalidasi apakah pemaparan informasi di dalam modul menggunakan pendekatan open ended. Instrumen ini berbentuk angket validasi aspektampilan untuk memvalidasi apakah tampilanmodultelah mampu membuat mahasiswa untuk belajar.
Instrumen ini berbentuk angket validasi aspek kepraktisan untuk memvalidasiapakah modul ini praktis untuk digunakan, baik di dalam maupun luar kelas. Instrumen tanggapan mahasiswa ini memvalidasi aspek keterbacaan modul oleh mahasiswa. Instrumen ini berbentuk angket dengan beberapa pernyataan yang disusun untuk mengetahui tingkat kepemahaman, daya tarik untuk membacanya, dan mendeteksi kosakata atau kalimat yang sulit dipahami oleh mahasiswa.

Setelah dilakukan penyebaran angket, jawaban pada angket tersebut diolah untuk memperoleh hasil keseluruhan dari jawaban responden (dosen atau mahasiswa). Adapun prosedur analisis data angket adalah (a) mengklasifikasi data, bertujuan untuk mengelompokkan jawaban berdasarkantiap butir pertanyaan pada angket; (b) menghitung frekuensi jawaban, berfungsi untuk memberikan informasi tentang kecenderungan jawabanresponden dalam setiap butir pertanyaan yang tertulis pada angket; dan (c) menghitung persentase jawaban responden, bertujuan untuk melihat besarnya persentase setiap jawaban dari pertanyaan sehingga data yang diperoleh dapat dianalisis sebagai temuan(Sudjana, 2005).

\section{HASIL PENELITIAN DAN PEMBAHASAN}

\section{A. Studi Pendahuluan}

Dalam studi pendahuluan, dilakukan analisis terhadap sumber belajar yang digunakan. Berdasarkan studi pendahuluan, perkuliahan Program Linier menggunakan buku ajar (belum ber-ISBN) yang disusun oleh dosen pengampu mata kuliah. Buku ajar tersebut telah memuat sembilan materi, yakni (1) penyelesaian masalah program linier dengan metode grafik dan simpleks, (2) metode Big M dalam me- 
maksimumkan fungsi tujuan, (3) persoalan meminimumkan, (4) dualitas, (5) degenerasi dual, (6) penyelesaian awal persoalan transportasi, (7) metode batu loncatan, (8) degenerasi pada persoalan transportasi, dan (9) persoalan penugasan.

Dalam buku ajar tersebut, sebelum masuk pada materi pertama, disajikan pendahuluan yang didalamnya terdapat penjelasan mengenai metode substitusi dan eliminasi yang dapat digunakan dalam menyelesaikan masalah program linier. Pada materi pertama, disajikan penyelesaian masalah program linier dengan metode grafik menggunakan garis selidik dan metode simpleks yang diawali dengan penjelasan istilah-istilah dalam simpleks. Pemaparan yang tertulis tentang simpleks ini cenderung belum jelas. Pada materi kedua, disajikan pemaparan yang cukup jelas terkait konsep metode Big $\mathrm{M}$ dalam memaksimumkan fungsi tujuan. Pada materi ketiga, disajikan pemaparan yang cukup jelas terkait persoalan meminimumkan. Pemaparan materi keempat terkait dualitas cenderung membingungkan. Pada bagian ini disajikan tabel simpleks dengan isian yang salah. Dilanjutkan pada pemaparan materi kelima, yakni degenerasi dual. Pada bagian ini tidak dipaparkan dengan jelas ciri-ciri tabel yang mengalami degenerasi dual. Pemaparan yang disajikan cenderung membingungkan. Materi berikutnya disajikan pada materi keenam mengenai penyelesaian awal persoalan transportasi. Materi keenam ini tidak diawali dengan pemaparan yang jelas. Pada materi ini dipaparkan metode north west corner rule (NWCR), VAM, dan Cij terkecil cukup jelas. Pemaparan materi ketujuh terkait metode batu loncatan dipaparkan dengan cukup jelas. Hanya saja, pemaparan istilah-istilah pada batu loncatan tidak dijelaskan dengan jelas.
Materi kedelapan, yakni degenerasi pada persoalan transportasi. Pemaparan materi ini sangat singkat dan cenderung tidak begitu jelas. Materi terakhir, yakni persoalan penugasan dipaparkan dengan singkat, sehingga cenderung masih membingungkan.

Berdasar pada hasil observasi pada perkuliahan Program Linier, perkuliahan tidak pernah menggunakan modul. Sumber belajar yang digunakan berupa buku ajar (belum ber-ISBN) yang disusun sendiri oleh dosen pengampu mata kuliah. Mahasiswa hanya mengandalkan buku belajar tersebut, tanpa mencari sumber belajar lain (meskipun sudah dihimbau untuk mencari sumber belajar lain yang banyak beredar, baik di pasaran maupun daring. Penggunaan modul diyakini akan membuat mahasiswa lebih aktif sehingga mampu mengkonstruk sendiri pemahamannya. Dalam perkuliahan untuk beberapa topik, dosen telah mengenalkan permasalahanpermasalahan open ended. Sebagain besar mahasiswa mengalami kesulitan dalam menyelesaikan permasalah open ended. Hal ini karena mahasiswa belum terbiasa dengan persoalan open ended yang memberikan kesempatan kepada mahasiswa untuk menginvestigasi berbagai strategi dan cara yang diyakininya sesuai dengan kemampuan mengelaborasi permasalahan. Perkuliahan yang berlangsung selama ini juga sudah memperhatikan pencapaian literasi matematis mahasiswa. Menurutnya, literasi matematis siswa sangat beragam. Hanya saja, dalam dua angkatan terakhir, literasi matematis sebagian besar mahasiswa tergolong rendah. Dengan memperhatikan karakteristik mahasiswa selama dua angkatan terakhir, penggunaan modul dengan pendekatan open ended akan membutuhkan pembimbingan yang lebih intensif mengenai 
permasalahan open ended di awal penggunaannya. Jika mahasiswa telah terbiasa dengan permasalahan open ended, penggunaan modul ini tidak akan mengalami kendala. Pengembangan modul dengan pendekatan open ended perlu dilakukan untuk memfasilitasi pencapaian literasi matematis oleh mahasiswa.

Berdasarkan pada hasil analisis angket yang diberikan kepada mahasiswa, diperoleh informasi sebagimana disajikan dalam Tabel 1.

Tabel 1. Hasil Analisis Angket Mahasiswa (Analisis Kebutuhan)

\begin{tabular}{|c|l|c|c|}
\hline No & $\begin{array}{c}\text { Aspek yang } \\
\text { Diukur }\end{array}$ & \multicolumn{2}{|c|}{ Persentase } \\
\cline { 3 - 4 } & Setuju & $\begin{array}{c}\text { Tidak } \\
\text { Setuju }\end{array}$ \\
\hline 1 & $\begin{array}{l}\text { Penggunaan } \\
\text { modul dalam } \\
\text { pembelajaran }\end{array}$ & 75,00 & 25,00 \\
\hline 2 & $\begin{array}{l}\text { Penggunaan } \\
\text { pendekatan } \\
\text { open ended } \\
\text { dalam } \\
\text { pembelajaran }\end{array}$ & 92,50 & 7,50 \\
\hline
\end{tabular}

Berdasar hasil analisis angket, $75 \%$ mahasiswa mengharapkan penggunaan modul sebagai sumber belajar dalam perkuliahan. Secara terperinci, $90 \%$ menyatakan bahwa mahasiswa mengalami kesulitan dalam memahami materi Program Linier melalui 1 (satu) buku ajar saja. Selama ini, mahasiswa hanya menggunakan 1 (satu) buku ajar yang disusun oleh dosen. Terkait penggunaan modul, sebanyak $80 \%$ mahasiswa menyatakan akan lebih mudah memahami materi Program Linier jika pembelajarannya menggunakan modul. Mahasiswa sebanyak 55\% menyatakan bahwa ia mampu membangun pemahaman sendiri tentang materi Program Linier jika pembelajarannya menggunakan modul.

Penggunaan pendekatan open ended dalam pembelajaran juga disambut baik oleh mahasiswa. Sebanyak $92,50 \%$ mahasiswa menyatakan setuju jika dalam pembelajaran Program Linier menggunakan pendekatan open ended. Secara terperinci, sebanyak $85 \%$ mahasiswa merasa senang menyelesaikan permasalahan yang penyelesaiannya bersifat terbuka. Lebih lanjut, $100 \%$ mahasiswa menyatakan akan lebih bersemangat jika penyajian masalah dalam proses pembelajarannya memberikan kesempatan untuk meginvestigasi berbagai cara penyelesaiannya.

Berdasarkan hasil analisis tersebut,buku ajar yang digunakan selama ini dalam perkuliahan Program Linier belum membantu mahasiswa dalam memahami konsep-konsep dalam mata kuliah Program Linier. Jika buku ajar ini tetap digunakan, diperlukan sumber belajar lain yang digunakan untuk membekali mahasiswa suatu pemahaman yang komprehensif terkait materi-materi pada mata kuliah Program Linier. Hadirnya modul dengan pendekatan open ended dalam perkuliahan diharapkan menjadi solusi dalam meningkatkan pemahaman konsep mahasiswa terkait materi-materi dalam perkuliahan Program Linier.

\section{B. Hasil Pengembangan Modul}

Modul dengan pendekatan open ended yang dikembangkan terdiri atas empat bagian yaitu bagian awal, pendahuluan, isi, dan penutup. Bagian awal terdiri atas 5 (lima) bagian yaitu sampul luar yang didesain menarik, sampul dalam, kata pengantar, dan daftar isi. Bagian pendahuluan terdiri atas 6 (enam) bagian yaitu pendahuluan yang berisi deskripsi modul, kedudukan modul, prasyarat, petunjuk penggunaan 
modul, standar kompetensi dan kompetensi dasar, serta cek kemampuan. Bagian pendahuluan ini disusun dengan tujuan memberikan informasi terkait hal-hal yang harus diperhatikan selama menggunakan modul. Pada akhir pendahuluan disajikan bagian cek kemampuan. Pada bagian ini, disajikan 3 (tiga) soal uraian. yang wajib dikerjakan oleh mahasiswa sebelum mempelajari modul. Hal ini bertujuan untuk mengukur kemampuan mahasiswa yang dijadikan dasar apakah mahasiswa tersebut harus mempelajari modul ini atau tidak. Apabila mahasiswa telah mampu menjawab tiga soal dengan benar, maka mahasiswa dapat melanjutkannya ke tes akhir, tanpa harus mempelajari modul. Bagian kegiatan belajar terdiri dari 13 (tiga belas) kegiatan belajar. Ketiga belas kegiatan belajar tersebut adalah (1) metode grafik, (2) metode simpleks, (3) metode Big $\mathrm{M}$ untuk memaksimumkan, (4) metode Big M untuk meminimumkan, (5) soal tidak layak, (6) dualitas, (7) degenerasi dual, (8) penyelesaian awal masalah transportasi, (9) metode batu loncatan, (10) degenerasi metode batu loncatan, (11) metode MODI, (12) degenerasi metode MODI, dan (13) masalah penugasan. Setiap kegiatan belajar disajikan pemaparan materi, rangkuman, dan tugas-tugas open ended untuk memfasilitasi pencapaian literasi matematis. Setiap kegiatan belajar diakhiri dengan pemberian balikan dan tidak lanjut.

Sebagai penutup, disajikan tes akhir untuk mengukur pemahaman konsep mahasiswa setelah mempelajari setiap kegiatan belajar. Tes akhir terdiri dari 3 (tiga) soal uraian. Apabila mahasiswa dapat memahami setiap kegiatan belajar dengan baik, dapat dipastikan mahasiswa dapat menyelesaikan tes akhir dengan benar. Modul ini disusun sesuai dengan rancangan yang telah dibuat. Pada tahap ini, diperoleh draf1 yang kemudian divalidasi oleh dua orang validator. Validasi dilakukan untuk menilai aspek materi, tampilan, dan kepraktisan. Validasi dilakukan dengan memberikanprint out moduldengan pendekatan open ended kepada validator, lalu meminta validator untuk memberi penilaian dengan mengisi

instrumenvalidasiberupaangketdan menuliskan saran untuk perbaikannya pada kolom yang telah disediakandalamangkettersebut. Setelah itu, modul draf 1 diperbaiki sesuai dengan saran yang diberikan oleh validator dan dikonsultasikan kembali kepada validator.

\section{Hasil Validasi oleh Validator}

Validasi ahli ini dilakukan oleh 2 (dua) orang validator. Komponen aspek materi yang divalidasi terdiri dari kesesuaianmateri dengan indikator, kesesuaian pemaparan materi, latihan/contoh soal, dan tugas dengan pendekatan open ended, kejelasan pemberian balikan dan tidak lanjutnya.Komponen aspek tampilan yang divalidasi terdiri dari desain sampul, tata letak, dan pemberian penekanan pada petunjuk-petunjuk khusus. Komponen aspek kepraktisan yang divalidasi terdiri dari pemilihan kalimat, penyediaan ruang jawab, dan penggunaan modul, baik di dalam maupun luar kelas. Tabel 2menunjukkan hasil validasi modul oleh validator.

Tabel 2. Hasil Validasi oleh Validator

\begin{tabular}{clcc}
\hline No & $\begin{array}{c}\text { Aspek yang } \\
\text { Diukur }\end{array}$ & $\begin{array}{c}\text { Persentase } \\
\text { Penilaian }\end{array}$ & $\begin{array}{c}\text { Kri- } \\
\text { teria }\end{array}$ \\
\hline 1 & Materi & 100,00 & Sesuai \\
\hline 2 & Tampilan & 87,50 & Sesuai \\
\hline 3 & Kepraktisan & 100,00 & Sesuai \\
\hline
\end{tabular}


Berdasarkan hasil validasi ahli, dapat diketahuibahwaditinjau dari aspek materi, pemaparan materi, latihan/contoh soal, dan tugas pada modul yang dikembangkan telah sesuai dengan indikator dan telah mengacu pada pendekatan open ended. Selain itu, balikan dan tindak lanjutnya pada setiap kegiatan disajikan secara jelas. Ditinjau dari aspek tampilan, desain sampul telah mencerminkan isi modul. Tata letak dan pemberian penekanan pada petunjukpetunjuk khusus telah sesuai dan jelas. Hanya saja, untuk tata letak pada bagian pendahuluan, validator menyarankan disajikan per bagian. Pemberian jarak antar bagian dimaksudkan agar isi pendahuluan tersebut dapat terbaca dengan jelas. Modul yang dikembangkan telah memenuhi aspek kepraktisan. Kepraktisan tersebut mencakup pemilihan kalimat, pemberian ruang untuk menjawab yang cukup, dan modul dimungkinkan untuk digunakan di dalam maupun luar kelas.

Setelah validasi ahli, modul direvisi sesuai dengan masukan dari validator dan dihasilkan draf 2. Modul yang dihasilkan memungkinkan peran aktif mahasiswa dalam mempelajari modul, melatih mahasiswa untuk lebih belajar mandiri, memudahkan mahasiswa untuk mempelajari dan memahami materinya secara bertahap hingga tuntas, disusun secara sistematis dan menarik, sehingga menumbuhkan minat membaca bagi mahasiswa. Modul ini dilengkapi dengan pemberian masalah-masalah yang sering dijumpai dalam kehidupan sehari-hari untuk membantu mahasiswa membangun konsep. Selain itu, modul juga dilengkapi dengan soal-soal open ended untuk memfasilitasi pencapaian literasi matematis mahasiswa.

\section{Hasil Uji Coba Terbatas}

Setelah modul dinyatakan valid oleh validator, dilakukan uji coba terbatas pada 10 orang mahasiswa Program Studi Pendidikan Matematika yang menempuh mata kuliah Program Linier. Uji coba terbatas ini hanya menilai aspek keterbacaan modul terhadap pengguna (mahasiswa). Persentase hasil tanggapan mahasiswa terhadap aspek keterbacaan modul ditunjukkan pada Tabel 3.

Tabel 3.Hasil Tanggapan Mahasiswa

\begin{tabular}{cccc}
\hline \multirow{2}{*}{ No } & $\begin{array}{c}\text { Aspek yang } \\
\text { Diukur }\end{array}$ & \multicolumn{2}{c}{ Persentase } \\
\cline { 3 - 4 } & Jelas & $\begin{array}{c}\text { Tidak } \\
\text { Jelas }\end{array}$ \\
\hline 1 & Keterbacaan & 97,78 & 2,22 \\
\hline
\end{tabular}

Berdasarkan hasil tanggapan mahasiswa dalam aspek keterbacaan, pemaparan isi modul dapat dipahami dengan baik oleh mahasiswa. Sebanyak 97,78\% mahasiswa menyatakan bahwa sajian modul dapat terbaca dengan jelas, mulai dari sajian sampul, kata pengantar, daftar isi, pendahuluan, cek kemampuan, kegiatan 1 sampai 13, tes akhir, dan daftar pustaka. Hanya saja, terdapat kesalahan pengetikan pada bagian tindak lanjut Kegiatan 1. Selanjutnya, modul diperbaiki berdasarkan masukan tersebut.

Aspek keterbacaan dibagi menjadi sub-aspek kemudahan dan kemenarikan. Sebagian besar mahasiswa menyatakan bahwa ukuran huruf (font) pada bagian luar dan isi modul sudah sesuai dan dapat terbaca dengan baik dan jelas, perpaduan warna teks pada bagian luar dan isi modul sudah serasi antara warna yang satu dengan yang lainnya dan dapat terbaca dengan baik, ukuran huruf (font) sudah sesuai dan dapat terbaca dengan baik. Tata letak gambar dengan tulisan/teks sudah tepat dan terlihat dengan jelas. Tampilan modul mempermudah pemahaman materi dan memberikan motivasi tambahan kepada mahasiswa untuk 
mempelajari materi. Mahasiswa menyatakan bahwa modul yang telah dikembangkan menarik minat pembaca untuk melihat dan mempelajari modul tersebut. Motivasi instrinsik seperti minat atau keinginan untuk belajar merupakan pengindikasi prestasi belajar yang lebih baik dari dibandingkan motivasi ekstrisik seperti keinginan untuk mendapat nilai tinggi (Pulfrey, Darnon dan Butera, 2013).

\section{KESIMPULAN DAN SARAN}

Kesimpulan dari penelitian ini, yaitu dihasilkannya produk pengembangan berupa modul dengan pendekatan open-ended. Berdasarkan hasil penelitian dan pembahasan, diperoleh kesimpulan bahwa:

1. Hasil analisis kebutuhan dari mahasiswa menunjukkan bahwa penggunaan modul dengan pendekatan open ended dalam perkuliahan Program Linier sangat diharapkan oleh mahasiswa. Sebanyak $75 \%$ mahasiswa menyatakan setuju untuk menggunakan modul dalam perkuliahan Program Linier. Sebanyak 92,5\% mahasiswa menyatakan setuju untuk menggunakan pendekatan open ended dalam perkuliahan Program Linier.

2. Karakteristik modul yang dikembangkan telah sesuai dengan kurikulum dan dirancang sesuai dengan pendekatan open-ended dengan penyajian masalah yang memberikan kesempatan kepada mahasiswa untuk meginvestigasi berbagai strategi dan cara yang diyakininya sesuai dengan kemampuan mengelaborasi permasalahan.

3. Tanggapan validator terhadap modul yang dikembangkan sudah sesuai ditinjau dari aspek materi, tampilan, dan kepraktisan.
Persentase penilaian aspek materi, tampilan, dan kepraktisan berturutturut sebesar $100 \%$ (sesuai), 87,5\% (sesuai), dan $100 \%$ (sesuai).

4. Tanggapan mahasiswa terhadap modul yang dikembangkan sudah baik ditinjau dari aspek keterbacaan. Persentase penilaian sebesar $97,78 \%$ bahwa isi modul dapat terbaca dengan jelas.

Berdasarkan penelitian yang telah dilakukan, disarankan agar dilakukannya (1) uji coba lapangan untuk mengetahui kelayakan modul yang dikembangkan dan (2) penelitian yang mengkaji tentang efektivitas pembelajaran Program Linier menggunakan modul dengan pendekatan open ended ditinjau dari pencapaian literasi matematis mahasiswa.

\section{DAFTAR PUSTAKA}

Asyhar, Rayanda.2011.Kreatif Mengembangkan Media Pembelajaran. Jakarta: Persada (GP) Press.

Ayers, T. et al. 1988. Computer Experiences in Learning Composition of Functions. Journal for Research in Mathematics Education. 19 (3), 246-259.

Depdiknas. 2008.Panduan Pengembangan Bahan Ajar. Jakarta: Depdiknas.

Johar, R. 2012. Domain Soal PISA untuk Literasi Matematika. Makalah disampaikan pada Semiloka tentang PISA, di Universitas Negeri Semarang.

OECD. 2013. PISA 2012 Assessment and Analytical Framework: Mathematics, Reading, Science, Problem Solving and Financial Literacy.

[Online]. 
[http://www.pisa.oecd.org. diakses pada 25 Februari 2016].

Pulfrey, C., Darnon, C., \& Butera, F. 2013. Autonomy and task performance: Explaining the impact of grades on intrinsic motivation. Journal of Educational Psychology, 105, 39-57.

Shimada, S. \&Becker, J.P. 1997. The Open-Ended Approach: A New Proposal for Teaching Mathematics. Virginia: NCTM.

Sudjana. 2005. Metode Statistika. Bandung: Tarsito.

Sugiman. 2008. Pandangan Matematika Sebagai Aktivitas Insani Beserta Dampak Pembelajarannya. Jurnal Pendidikan Matematika (Nomor 2 tahun 2008). Hlm. 6171.

Sugiyono. 2008. Metode Penelitian Pendidikan (Pendekatan
Kuantitatif, Kualitatif, dan $R \& D)$ Cetakan Ke-6. Bandung: Alfabeta.

Suherman, E. 2003. Strategi Pembelajaran Matematika Kontemporer. Bandung: JICA.

Sukmadinata. 2011. Metodologi Penelitian Pendidikan.

Bandung: Remaja Rosdakarya.

Suparno. 2001. Teori Perkembangan Kognitif Jean Piaget. Jogjakarta: Kanisius.

Wena, Made. 2009.Strategi Pembelajaran Inovatif Kontemporer: Suatu Tinjauan Konseptual operasional. Malang: Bumi Aksara. 